\title{
Inhibition of human pathogenic fungi by ethnobotanically selected plant extracts
}

\section{Hemmung humanpathogener Pilze durch ethnobotanisch ausgewählte Pflanzenextrakte}

\author{
Christine E. Ficker, ${ }^{1}$ J. T. Arnason, ${ }^{2}$ P. S. Vindas, ${ }^{3}$ L. P. Alvarez, ${ }^{4}$ K. Akpagana, ${ }^{4}$ M. Gbéassor, ${ }^{4}$ \\ C. De Souza ${ }^{4}$ and M. L. Smith ${ }^{1}$
}

${ }^{1}$ Biology Department, Carleton University, Ottawa, Ontario, Canada; ${ }^{2}$ Department of Biology, University of Ottawa, Ottawa, Ontario, Canada; ${ }^{3}$ Herbario Juvenal Valerio Rodriguez, Universidad Nacional, Heredia, Costa Rica and ${ }^{4}$ Centre de Recherche et de Formation sur les Plantes Médicinales, Université du Bénin, Lomé, Togo

\begin{abstract}
Summary In this study, 36 extracts derived from 29 plant species selected using an ethnobotanical approach were tested for antifungal activity against a taxonomically diverse group of 13 human pathogenic fungi. We compared the inhibitory characteristics of these plant extracts with those of the commonly used antifungals, amphotericin B and ketoconazole, and the plant-derived antifungal, berberine. Several plant extracts, notably those from Zingiber officinale (ginger) and Juglans cinerea (butternut), had pronounced antifungal activity against a wide variety of fungi, including strains that were highly resistant to amphotericin B and ketoconazole. Further exploration of Z. officinale as an antifungal is warranted as this species is generally regarded as safe for human consumption.
\end{abstract}

Zusammenfassung Es wurden 36 Extrakte von 29 Pflanzenarten auf ihre antimyzetische Aktivität gegen 13 humanpathogene Pilzarten untersucht. Die Hemmcharakteristik dieser Pflanzenextrakte wurde mit der von Amphotericin B, Ketoconazol und Berberin verglichen. Mehrere Pflanzenextrakte, besonders die von Zingiber officinale (Ingwer) und Juglans cinerea (Butternuss) zeigten eine deutliche antimyzetische Aktivität gegen ein breites Pilzspektrum einschließlich solcher Stämme, die hochresistent gegen Amphotericin B und Ketoconazol waren. Die weitere Untersuchung der antimyzetischen Aktivität von Z. officinale erscheint vielversprechend, da diese Art allgemein als sicher für menschlichen Konsum angesehen wird.

Key words: antifungal activity, plants, phytomedicine.

Schlüsselwörter: Antimyzetishce Aktivität, Pflanzen, Phytomedizin.

Correspondence: Professor Dr Myron L. Smith, Department of Biology,

Carleton University, Ottawa, Ontario K1S 5B6 Canada.

Tel.: +1-613-5202600. Fax: +1-613-5202569.

E-mail: mysmith@ccs.carleton.ca

Accepted for publication 19 February 2002 


\section{Introduction}

During the past decade there has been an increase in the number of patients with alterations in immune status associated with human immunodeficiency virus (HIV), cancer chemotherapy and organ and bone marrow transplantations. Coinciding with this rise in the immunocompromised patient population has been an increase in the incidence of human systemic mycoses (reviews in: ${ }^{1-3}$ ). Amphotericin B and the azole group of antifungal agents have been used extensively in the treatment of fungal infections. Unfortunately, the widespread use of these antifungals has led to the emergence of drug resistance in several common pathogenic fungi. ${ }^{4,5}$ In addition, fungi that were previously regarded as saprobes are now occurring on human hosts, with some of these fungal strains having an innate resistance to the presently available antifungal drugs. ${ }^{1,6-8}$

Due to this emergence of antibiotic resistant human pathogenic fungi, it is of great importance to develop new antifungal agents. The field of ethnobotanical research has expanded greatly in recent years as the value of this type of research in identifying novel therapeutics has come to be more widely recognized. ${ }^{9}$ Using an ethnobotanical approach, this study identifies plant extracts with significant antifungal activities that are appropriate for further study and development as antifungal phytomedicines. The inhibitory characteristics of 36 extracts from 29 plant species used in traditional remedies are reported and compared with those of amphotericin B and ketoconazole. A taxonomically diverse group of human pathogenic fungi were tested to determine their susceptibilities to amphotericin B and ketoconazole, from which 13 strains were selected for use in the plant extract assays. An analysis of published literature using the NAPALERT database (obtained from the University of Illinois) revealed that, although the traditional uses of most of the plant species used in this study are well documented, few have been tested for antifungal activity against a broad range of fungi.

\section{Materials and methods}

\section{Plant material and extract preparation}

Extracts from 29 plant species (Table 1), representing 16 families, that are used in traditional remedies were obtained from the University of Ottawa Herbarium; 11 were from Togo, West Africa, 12 were from Costa Rica, Central America, and six were from Eastern Ontario, Canada. Plants were collected and preserved in alcohol in the field, then transported to the lab for processing.
The preserved plant material was ground in a blender with ethanol $(1: 3 \mathrm{w} / \mathrm{v})$, then filtered and the solvent was roto-evaporated at $45{ }^{\circ} \mathrm{C}$ to near dryness, after which the extract was freeze-dried for $48 \mathrm{~h}$ to achieve complete dryness. Two hundred milligrams of the dried extract was reconstituted in $1 \mathrm{~mL}$ ethanol for a final concentration of $2 \mathrm{mg} / 10 \mu \mathrm{L}$. More than one plant part of six of the species was extracted, resulting in a total of 36 extracts.

\section{Fungal strains and inoculum preparation}

The sources of yeast-like and filamentous fungi used in this study are given in Table 2. The strains are all opportunistic human pathogens. Fungi were cultured on Sabouraud glucose agar medium at $30^{\circ} \mathrm{C}$ and are maintained at Carleton University, (Ottawa, ON, Canada). All transfers of fungal strains were carried out under a biological containment hood (Bioclone2, Microzone, Ottawa, ON, Canada). Inocula of yeast-like fungi were prepared in liquid Sabouraud glucose broth and adjusted to an $\mathrm{OD}_{600}$ of $\sim 2.0$. Inocula of filamentous fungi were prepared by placing a $1 \times 2 \mathrm{~cm}$ block of agar medium containing hyphae from the colony margin into $10 \mathrm{~mL}$ of Sabouraud glucose broth and fragmenting the hyphae for $1.5 \mathrm{~min}$ at high speed in a water-cooled Waring blender.

\section{Disk diffusion bioassays}

Fungal inoculum $(150 \mu \mathrm{L})$ was spread onto Sabouraud glucose agar plates with a sterile bent glass rod. Three sterile 3M paper discs, $7.5 \mathrm{~mm}$ in diameter, were impregnated with $10 \mu \mathrm{L}(2 \mathrm{mg})$ of ethanolic plant extract, allowed to air dry and placed face down on the inoculated agar surface. A negative control consisting of $10 \mu \mathrm{L}$ DMSO and a positive control consisting of $2 \mathrm{mg}$ berberine in $10 \mu \mathrm{L}$ of ethanol were also prepared.

To test for ultraviolet light effects on antifungal activity of the plant extracts, dark and UV-light treatments were performed. For UV-light treatments, disks impregnated with plant extracts were placed onto freshly inoculated Petri dishes and irradiated with $10 \mathrm{~W} / \mathrm{m}^{2}$ for $2 \mathrm{~h}$ using three $20 \mathrm{~W}$ black light blue tubes (320-400 nm range). For dark treatments, plates were wrapped in aluminium foil for $2 \mathrm{~h}$ prior to incubation. All treatments were incubated in the dark at $30{ }^{\circ} \mathrm{C}$ for $48 \mathrm{~h}$ at which time the diameter of the fungal growth inhibition zone was recorded. An extract was classified as having antifungal activity when the diameter of the inhibition zone was $\geq 8 \mathrm{~mm}, 0.5 \mathrm{~mm}$ larger than the diameter of the paper disk. Fungi 
Table 1 Origin of plant species tested and their uses in traditional medicine.

\begin{tabular}{|c|c|c|c|}
\hline Origin, species & Family & Designation & Traditional medicinal usage ${ }^{1}$ \\
\hline \multicolumn{4}{|l|}{ Togo } \\
\hline Euphorbia hirta L & Euphorbiaceae & UO-18554 & Intestinal pain, wounds, antimicrobial \\
\hline Euphorbia odoratum L & Euphorbiaceae & UO-18557 & $\begin{array}{l}\text { Malaria, astringent, antispasmodic, antihypertensive, cough, } \\
\text { anti-inflammatory }\end{array}$ \\
\hline \multicolumn{4}{|l|}{ Harungana } \\
\hline madagascariensis (Lam.) Poir. & Hypericaceae & UO-18555 & $\begin{array}{l}\text { Emmenagogue, abortive, aphrodisiac, facilitate birth, } \\
\text { interrupt menses, antidiarrheal }\end{array}$ \\
\hline Mormodica charantia L & Cucurbitaceae & UO-18552 & Laxative, diseases of the spleen and liver, gout, rheumatism, diabetes \\
\hline Phyllanthus amarus L & Euphorbiaceae & UO-18550 & Jaundice, stomach ache, skin diseases, colds \\
\hline Pleiocarpa mutica Benth. & Burseraceae & UO-18558 & Fever, malaria \\
\hline Psidium guajave L & Myrtaceae & UO-18556 & Malaria, diarrhea, dysentery \\
\hline \multicolumn{4}{|l|}{ Trema guineensis } \\
\hline (Schum. \& Thonn.) Ficalho & Ulmaceae & UO-18551 & $\begin{array}{l}\text { Bronchial congestion, asthma, anthelmintic, antispasmodic, } \\
\text { female infertility }\end{array}$ \\
\hline Veronia conferta von Schreber & Asteraceae & UO-18560 & $\begin{array}{l}\text { Increase lactation, aphrodisiac, sleeping sickness, cough, } \\
\text { stomach ache, antiparasitic }\end{array}$ \\
\hline Ximenia americana L. & Olacaeae & UO-18559 & Anthelmintic \\
\hline Zingiber officinale Roscoe & Zingibereaceae & UO-17722 & Cough, tuberculosis, bronchitis, malaria, antimicrobial, contraceptive \\
\hline \multicolumn{4}{|l|}{ Costa Rica } \\
\hline Cabralea sp. (bark) & Meliaceae & UO-19049 & Antimicrobial \\
\hline Cedrela odorata L & Meliaceae & UO-19089 & Wounds, abdominal pain, chills, cough, malaria \\
\hline Cedrela salvadorensis L & Meliaceae & UO-19025 & Gastrointestinal pain, chills, abortive \\
\hline Piper tuberculatum L & Pipereaceae & UO-19061 & $\begin{array}{l}\text { Regulate menstrual cycle, bronchial infections, cough, } \\
\text { female infertility, gonorrhea, syphilis }\end{array}$ \\
\hline Protium glabrum (Rose) Engl & Burseraceae & UO-19053 & Anti-inflammatory, analgesic \\
\hline Protium panamensis (Rose) I. M. Johnst & Burseraceae & UO-19054 & Anti-inflammatory \\
\hline Renealmia aromatica (Aubl.) Griseb & Zingibereaceae & UO-19052 & Febrifuge \\
\hline Swietenia mahogoni $\mathrm{L}$ & Meliaceae & UO-19046 & Malaria, diabetes, postpartum hemorrhage, hypertension, diarrhea \\
\hline Trichilia americana (fruit) Browne, P & Meliaceae & UO-19013 & Antiprotozoal \\
\hline Trichilia glabra L & Meliaceae & UO-19020 & Antiprotozoal \\
\hline Trichilia pleena (A. Juss.) C. DC. & Meliaceae & UO-19002 & Antimalarial \\
\hline Trichilia triflolia Browne, P & Meliaceae & UO-18464 & Purgative, abortive, emmenagogue \\
\hline \multicolumn{4}{|l|}{ Ontario (eastern Canada) } \\
\hline Acer rubrum L & Aceraceae & UO-18500 & Antimicrobial \\
\hline Acer saccharum Marsh. & Aceraceae & UO-18501 & Antimicrobial \\
\hline Betula papyrifera Marsh. & Betulaceae & UO-18502 & Antimicrobial \\
\hline Juglans cinerea L & Juglandaceae & UO-18507 & Antimicrobial \\
\hline Prunus serotina Ehrh. & Rosaceae & UO-18508 & Antimicrobial \\
\hline Quercus rubra L & Fabaceae & UO-18511 & Antimicrobial \\
\hline
\end{tabular}

${ }^{1}$ Sources = NAPALERT database, University of Illinois; 31.

showing growth inhibition when treated with nine $(25 \%)$ or more of the plant extracts were considered extract susceptible. This value is somewhat arbitrary but serves as a frame of reference against which the antifungal susceptibility of the fungi can be compared.

\section{Amphotericin B and ketoconazole minimum inhibitory concentration (MIC) bioassays}

Antifungal susceptibility testing was based on standardized method. ${ }^{10}$ Minimum inhibitory concentration (MIC) values were recorded as the lowest tested concentration of antifungal activity that resulted in a prominent reduction $(\geq 80 \%)$ of fungal growth. The MIC bioassays were performed in sterile, disposable microtiter plates (Costar, 96 V-shaped well). Fungal inoculum, prepared as described above, was diluted with Sabouraud glucose broth $(1: 500)$ to obtain $\sim 10^{3} \mathrm{CFU} / \mathrm{mL}$. One hundred microliters of the diluted fungal inoculum was dispensed into each microtiter well within a row. A three-fold dilution was performed from an initial amphotericin B (Sigma, Oakville, ON, Canada) or ketoconazole (Sigma, Oakville, ON, Canada) concentration of $90 \mu \mathrm{g} / \mathrm{mL}$ in the first microtiter well to a final concentration of $0.005 \mu \mathrm{g} / \mathrm{mL}$ in the second to last 
microtiter well. The last well in each row served as a drug-free control. Using the three-fold dilution series resulted in a large gap of untested antifungal concentrations from 30 to $90 \mu \mathrm{g} / \mathrm{mL}$. To define MIC values within this range, bioassays were subsequently repeated using a 0.25 step-wise dilution ranging from 6.8 to $90 \mu \mathrm{g} / \mathrm{mL}$. Microtiter plates were sealed with parafilm and maintained stationary in the dark at $30{ }^{\circ} \mathrm{C}$ for $48 \mathrm{~h}$ at which time they were examined for fungal growth. The MIC assays were performed independently at least three times for each fungal strain/antifungal combination.

\section{Results}

We examined the susceptibility of 22 fungal strains to amphotericin B and ketoconazole (Table 2). For filamentous fungi, we used hyphal fragments as inoculum rather than conidia for our assays, the rationale being that inhibiting the growth of hyphae is more relevant to pathogenesis than is conidial germination. In addition, not all of the filamentous fungal strains we used readily produced conidia. Fungi with MIC values above $\sim 2 \mu \mathrm{g} / \mathrm{mL}$ for amphotericin B and $\sim 8 \mu \mathrm{g} / \mathrm{mL}$ for ketoconazole were considered antifungal resistant based on

Table 2 Infection types and minimum lethal concentration (MLC) values of fungal strains used in this study.

\begin{tabular}{|c|c|c|c|c|}
\hline \multirow[b]{2}{*}{ Fungal species/strain } & \multirow[b]{2}{*}{ Source $^{1}$} & \multirow[b]{2}{*}{ Infection types ${ }^{2}$} & \multicolumn{2}{|c|}{ MLC values $(\mu \mathrm{g} / \mathrm{mL})$} \\
\hline & & & Amphotericin B & Ketoconazole \\
\hline \multicolumn{5}{|l|}{ Yeast-like } \\
\hline Candida albicans (Robin) Berkhout & & Systemic and subcutaneous infections & & \\
\hline D10 & N. D. Lees & & 90 & $>90$ \\
\hline CN1A & N. D. Lees & & 90 & 90 \\
\hline al-1 & OGH-308-1329 & & 1.1 & 0.37 \\
\hline al-2 & OGH-311-0628 & & 1.1 & 0.12 \\
\hline al-3 & OGH-312-0305 & & 3.3 & 30 \\
\hline al-4 & OGH-316-0588 & & 1.1 & 0.13 \\
\hline al-5 & OGH-316-0504 & & 1.1 & 30 \\
\hline al-6 & OGH-316-433 & & 3.3 & 10 \\
\hline al-7 & OMH-FR2853 & & & \\
\hline Candida krusei (Castellani) Berkhout & & Systemic and subcutaneous infections & & \\
\hline $\mathrm{kr}-1$ & OGH-238-0967 & & 3.3 & 10 \\
\hline $\mathrm{kr}-2$ & OMH-FR2428 & & 1.1 & 3.3 \\
\hline \multicolumn{5}{|l|}{ Candida kefyr (Beijerinck) } \\
\hline van Uden et Buckley & OGH-301-0788 & Systemic and subcutaneous infections & 3.3 & 0.13 \\
\hline \multicolumn{5}{|l|}{ Candida glabrata (Anderson) } \\
\hline Meyer et Yarrow & OGH-299-378 & Systemic and subcutaneous infections & 3.3 & 0.13 \\
\hline \multicolumn{5}{|l|}{ Cryptococcus neoformans (Sanfelice) } \\
\hline Vuillemin & OMH-FR2704 & $\begin{array}{l}\text { Systemic and subcutaneous infections, } \\
\text { menigingoencephalitis }\end{array}$ & 0.04 & 0.04 \\
\hline Saccharomyces cerevisiae Hansen & ATCC 48252 & $\begin{array}{l}\text { Systemic infections in immunocompromised } \\
\text { patients }\end{array}$ & 0.37 & 1.1 \\
\hline Wangiella dermatitidis (Kano) McGinnis & OMH-FR2236 & $\begin{array}{l}\text { Cutaneous infections and central } \\
\text { nervous system }\end{array}$ & $>90$ & 30 \\
\hline \multicolumn{5}{|l|}{ Filamentous } \\
\hline Alternaria alternata (Fries) Keissler & OMH-FR9884 & Cutaneous and subcutaneous infections & 0.37 & 0.37 \\
\hline Aspergillus fumigatus Fresenius & OMH-FR2837 & Respiratory, subcutaneous infections & 1.1 & 10 \\
\hline $\begin{array}{l}\text { Fusarium oxysporum Schlechtendahl } \\
\text { Microsporum gypseum (Bodin) }\end{array}$ & OMH-FR6448 & Keratomycosis, subcutaneous infections & 90 & $>90$ \\
\hline $\begin{array}{l}\text { Guiart et Grigorakis } \\
\text { Pseudallescheria boydii (Shear) }\end{array}$ & OMH-FR2385 & Tinea corporis, tinea pedis & 30 & 30 \\
\hline McGinnis et al. & OMH-FR2625 & Sinusitis, central nervous system colonizer & 67.5 & 90 \\
\hline $\begin{array}{l}\text { Rhizopus sp. } \\
\text { Trichophyton mentagrophytes (Robin) }\end{array}$ & OMH-FR2874 & Invasion of tissue and surrounding vessels & 0.01 & 30 \\
\hline Blanchard & OMH-T2379 & Tinea corporis, tinea pedis & 67.5 & 67.5 \\
\hline
\end{tabular}

${ }^{1}$ N.D. Lees, IUPUI, Indianapolis IN USA; OGH, Ontario General Hospital, Ottawa ON Canada, OMH, Ontario Ministry of Health, Toronto, ON Canada, ATCC, American type culture collection.

${ }^{2}$ Sources: ${ }^{2,6,8,32,33-35}$. 
therapeutic concentrations reported in the literature (reviews in: ${ }^{3,4,11}$ ). Most of the yeast-like strains were susceptible to both antifungals at or below these concentrations, with the exception of $C$. albicans strains D10, CN1A, al-3 and al-5, and $W$. dermatitidis, which were resistant to either amphotericin B or ketoconazole, or to both. Notably, all filamentous fungi except A. alternata were resistant to at least one of the two antifungals. The amphotericin B and ketoconazole MIC values given in Table 2 are compatible with values reported for the fungal species examined, which tend to vary in a strain-specific manner. ${ }^{12-16}$ From these initial susceptibility assays, we selected 13 fungal strains that showed a wide range of susceptibility to the antifungals, and represented both yeast-like and filamentous growth forms. The strains selected were $C$. albicans strains al-1, D10, and CN1A, Cr. neoformans, S. cerevisiae, W. dermatitidis, A. alternata, A. fumigatus, F. oxysporum, M. gypseum, $P$. boydii, Rhizopus sp. and T. mentagrophytes.

The results of testing the 36 ethanolic plant extracts and berberine against these six yeast-like and seven filamentous fungi are summarized in Table 3. Notably, the plant-derived berberine is a highly effective inhibitor of a wide variety of fungi. Of the 36 crude plant extracts tested, all but six (E. hirta leaves, P. amarus leaves, $V$. conferta leaves, Cabralea spp. bark, $C$. odorata fruit and T. pleena bark) were inhibitory to the growth of at least one fungal strain. Photoactivation of plant-derived inhibitors is commonly observed. ${ }^{17}$ Significant effects (positive or negative) on antifungal activities of plant extracts by the UV-light treatment were observed in several cases (Table 3). For example, UV-light exposure enhanced the inhibitory effects of $J$. cinerea bark extract on Cr. neoformans and S. cerevisiae. However, the UV-light treatment of J. cinerea wood extract caused a reduction in the zone of inhibition in disk assays with C. albicans strain D10.

Figure 1 shows a trend whereby fungal strains that are inhibited by larger numbers of extracts also tend to have larger zones of inhibition by any given extract. Using either criterion, mean inhibition zone diameter or number of plant extracts that inhibit growth (Fig. 2), we found that 11 fungi fell into one of three distinct groups. Group 1 included C. albicans strains CN1A and D10, T. mentagrophytes, $W$. dermatitidis and M. gypseum, all of which were neither susceptible to amphotericin B (MIC $\geq 2 \mu \mathrm{g} / \mathrm{mL}$ ) nor to ketoconazole (MIC $\geq 8 \mu \mathrm{g} / \mathrm{mL}$ ) but were inhibited by $>25 \%$ of plant extracts. Group 2 included $F$. oxysporum and $P$. boydii, which were neither susceptible to antifungal activity nor to $\leq 25 \%$ of the plant extracts tested. Finally, group 3 strains, A. alternata, C. albicans strain al-1, Cr. neoformans and
S. cerevisiae, were susceptible to both antifungals and to $\leq 25 \%$ of the plant extracts. The strains representing Rhizopus sp. and A. fumigatus fell into groups 2 and 3 as both were susceptible to amphotericin B but not to ketoconazole. Evidently, several fungi (group 1) that are not susceptible to commonly used antifungals may be inhibited by several plant-derived compounds. The C. albicans strains D10 and CN1A that are highly resistant to amphotericin $\mathrm{B}$ and ketoconazole, for example, are inhibited by 13 and 12 of the plant extracts, respectively. The M. gypseum strain proved to be the most susceptible to the plant-derived growth inhibitors but was not susceptible to amphotericin B or to ketoconazole. The pattern associated with group 2 suggests that the active compounds in the plant extracts have different modes of action from either of the antifungals tested. Both amphotericin B and azole antifungals target ergosterol, the major sterol component of the fungal plasma membrane (reviews in: ${ }^{3,4,11,18,19}$ ). Amphotericin B, a polyene antifungal, is believed to act primarily by binding to ergosterol and forming channels in the membrane through which cellular components, particularly potassium ions, leak, thereby destroying the proton gradient and causing cell death. Ketoconazole and other azoles act primarily by inhibiting lanosterol 14- $\alpha$ demethylase, a cytochrome P450-dependent enzyme involved in the conversion of lanosterol to ergosterol. Azole exposure results in the accumulation of $14 \alpha$-methylsterols which induce a variety of functional alterations including membrane leakiness, changes in membrane-bound enzymes and inhibition of growth. The strains $\mathrm{CN} 1 \mathrm{~A}$ and D10 have mutations that effect the P-450 ergosterol biosynthetic pathway and result in a decreased cell membrane ergosterol content and resistance to ketoconazole and amphotericin B. ${ }^{5,20,21}$ These alterations may increase the permeability of the cell membrane, and thus the sensitivity of the group 1 strains to growth inhibitors in the plant extracts. By extension, the resistance to amphotericin B and ketoconazole displayed by the fungi in group 2, F. oxysporum and P. boydii, is likely achieved by a different mechanism than alterations in the cell membrane ergosterol content, as these fungi are also quite resistant to inhibition by the plant extracts. Other potential means of resistance, including altered uptake mechanisms and increased activity of efflux pumps. (review in: ${ }^{4}$ ), may result in general insensitivity to a wide variety of inhibitors. Because of the overall resistance of the pathogens belonging to group 2, inhibitors of fungi in this group should be actively pursued.

Plant extracts with inhibitory activity against five or more fungal strains included $M$. charantia leaves, 


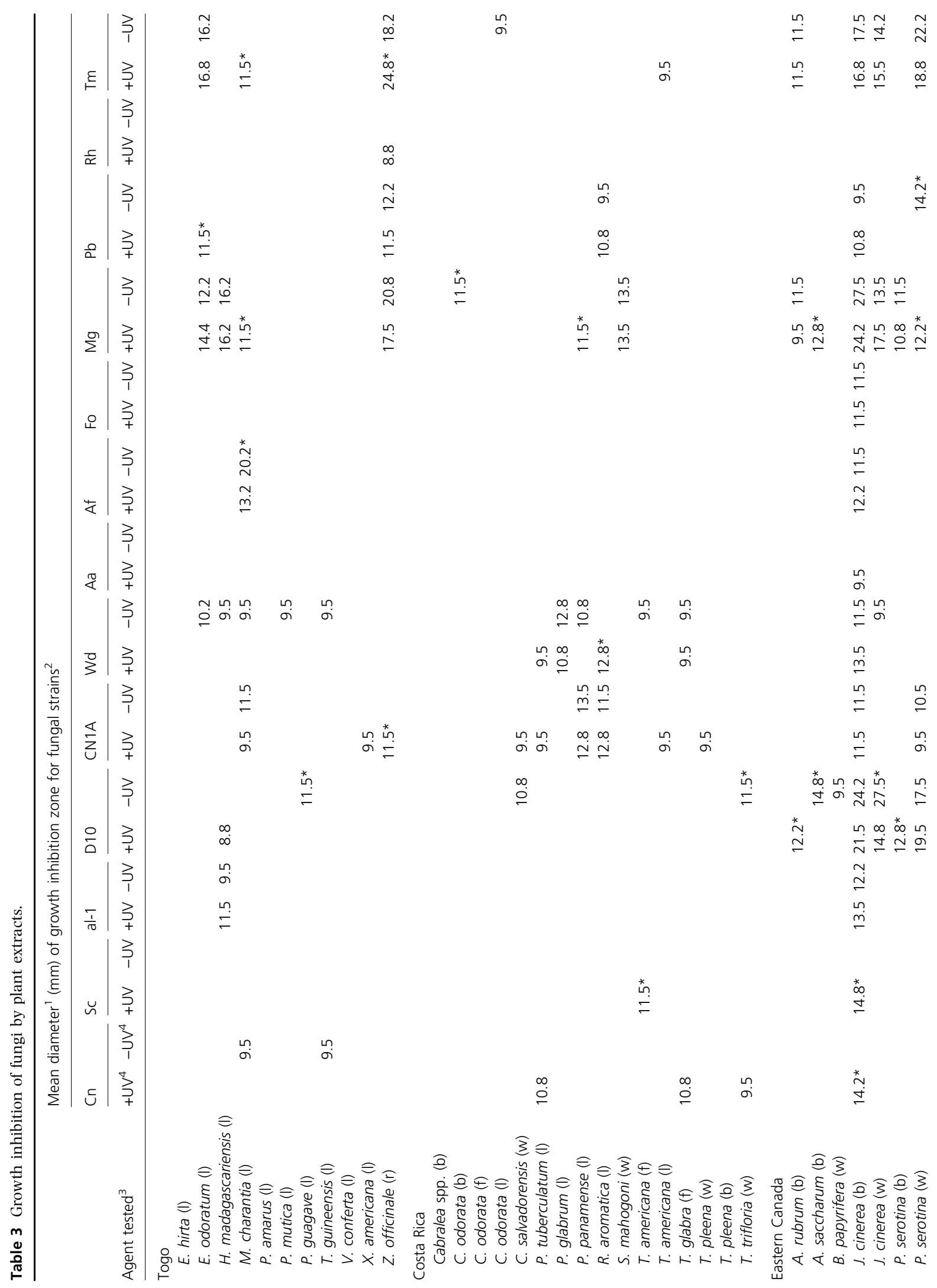




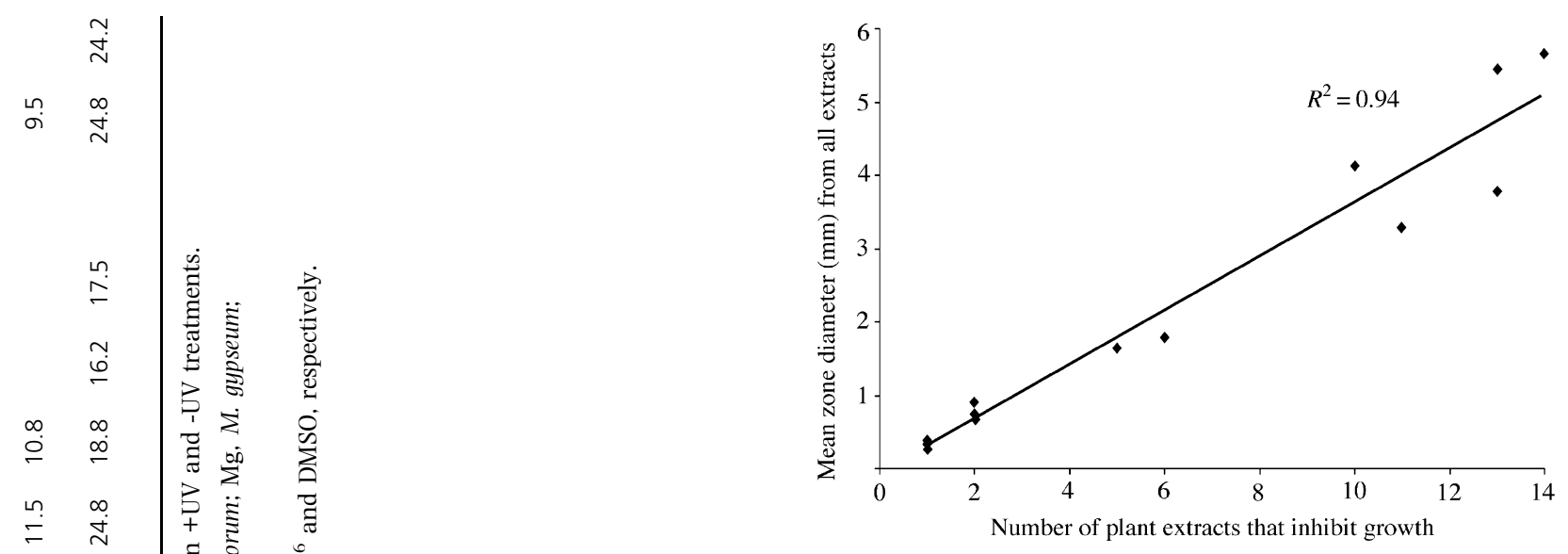

Figure 1 Correlation between mean inhibition zone diameters and number of plant extracts that inhibit fungal strains (from Table 3).

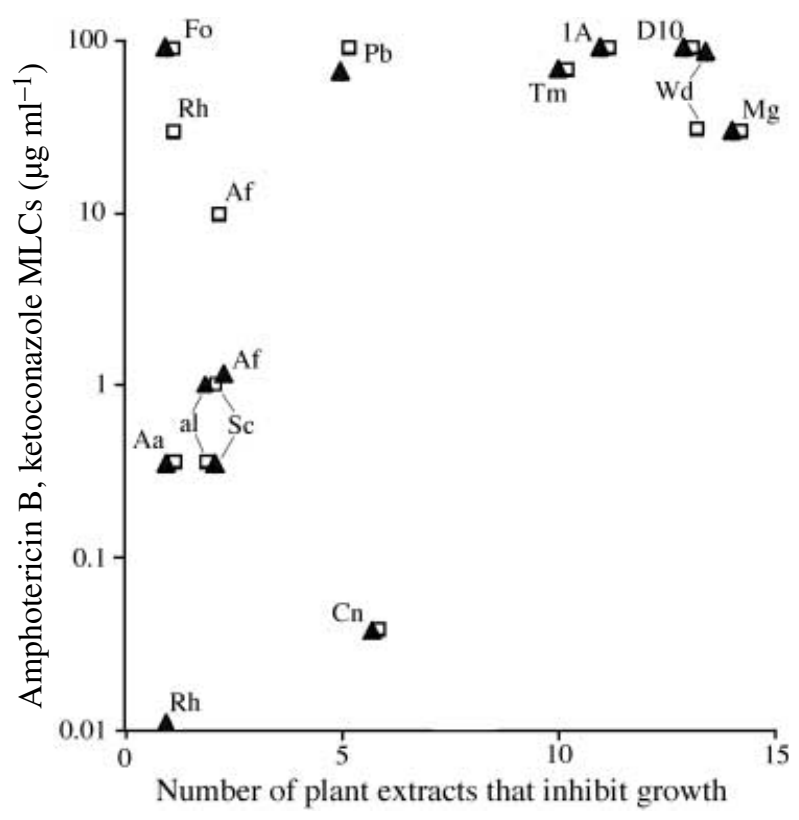

Figure 2 Comparison of inhibition of fungal strains by ketoconazole (open squares) or amphotericin B (closed triangles) and by plant extracts. Susceptibility to ketoconazole and amphotericin B is considered to be about $\geq 2 \mu \mathrm{g} / \mathrm{mL}$ and $\geq 8 \mu \mathrm{g} / \mathrm{mL}$, respectively. Fungi that were inhibited by nine $(25 \%)$ or more of the 36 plant extracts tested were considered extract sensitive. C. albicans strains al-1 (al), CN1A (1A) and D10, T. mentagrophytes (Tm), W. dermatitidis (Wd), M. gypseum (Mg), F. oxysporum (Fo), P. boydii (Pb), Rhizopus sp., (Rh)A. fumigatus (Af), A. alternata (Aa), C. neoformans (Cn), S. cerevisiae $(\mathrm{Sc})$.

Z. officinale rhizome, J. cinerea bark, Q. rubra bark and $P$. serotina wood. Of the extracts tested, J. cinerea bark and Z. officinale rhizome demonstrated the broadest range of antifungal activity, measured as either the number of fungi inhibited or as the average diameter of 
the zones of inhibition. Fungi inhibited by J. cinerea bark and Z. officinale rhizome included those in group 2. Of particular interest, only the Z. officinale rhizome extract exhibited activity against the Rhizopus sp. strain that was not inhibited by berberine, ketoconazole or any other plant extracts tested. Likewise, J. cinerea bark was the only extract inhibiting the growth of the amphotericin B- and ketoconazole-resistant $F$. oxysporum strain.

\section{Discussion}

Additional antifungal agents must be developed to successfully control the new and emerging human fungal pathogens resistant to available antifungals. Intense selective pressure on plants by fungal pathogens has resulted in the evolution of a wide range of phytochemicals with antifungal activity. In this study, a survey of plant species important in traditional medicines was conducted to identify species with antifungal activity. Their traditional uses suggest that these plants are favored by low overall toxicity to humans. While none of the extracts from these plant species inhibited growth of all fungal strains, several extracts, especially those from J. cinerea bark and Z. officinale rhizome, were identified as having pronounced antifungal activities toward a wide range of fungi.

J. cinerea bark was previously found to be a potent antibacterial agent. ${ }^{17}$ The antimicrobial activity of J. cinerea is thought to be the result of the presence of quinones. ${ }^{22}$ The potential toxicity of quinones renders these extracts unsafe for use against systemic mycoses but is of potential value as a topical antifungal. Extracts of Z. officinale have been reported to possess numerous biological activities ${ }^{23-26}$ and have been used extensively in antinausea clinical trials, ${ }^{27-29}$ including trials conducted in pregnant women. ${ }^{30}$ As adverse side-effects have not been reported in any of the clinical trials, Z. officinale is generally regarded as safe for human use and further investigation into the antifungal activity of this species and its possible use as a phytomedicine is warranted.

\section{Acknowledgements}

This work was funded by Research Grants to MLS and JTA through the Natural Sciences and Research Council of Canada (NSERC).

\section{References}

1 Graybill JR. The future of antifungal therapy. Clin Infect Dis 1996; 22 (Suppl. 2): S166-S178.
2 Perfect JR, Schell WA. The new fungal opportunists are coming. Clin Infect Dis 1996; 22 (Suppl. 2): S112-S118.

3 White TC, Marr KA, Bowden RA. Clinical, cellular, and molecular factors that contribute to antifungal drug resistance. Clin Microbiol Rev 1998; 11: 382-402.

4 Alexander BD, Perfect JR. Antifungal resistance trends towards the year 2000. Implications for therapy and new approaches. Drugs 1997; 54: 657-78.

5 Jensen-Pergakes KL, Kennedy MA, Lees ND, Barbuch R, Koegel C, Bard M. Sequencing, disruption and characterization of the Candida albicans sterol methyltransferase (ERG6) gene: drug susceptibility studies in erg6 mutants. Antimicrob Agents Chemother 1998; 42: 1160-7.

6 Anaissie EJ, Bodey GP, Rinaldi MG. Emerging fungal pathogens. Eur J Clin Microbiol Infect Dis 1989; 8: 323-30.

7 Walsh M, White L, Atkinson K, Enno A. Fungal Pseudallescheria boydii lung infiltrates unresponsive to amphotericin B in leukaemic patients. Aust N Z J Med 1992; 22: 265-8.

8 Vartivarian SE, Anaissie EJ, Bodey GP. Emerging fungal pathogens in immunocompromised patients: classification, diagnosis, and management. Clin Infect Dis 1993; 17 (Suppl. 2): S487-91.

9 McCutcheon AR, Ellis SM, Hancock REW, Towers GNH. Antibiotic screening of medicinal plants of the British Columbian native peoples. J Ethnopharmacol 1992; 37: 213-23.

10 Rex JH, Pfaller MA, Walsh TJ et al. Antifungal susceptibility testing: practical aspects and current challenges. Clin Microbiol Rev 2001; 14: 643-58.

11 Vanden Bossche H, Willemsens G. Marichal P. Anti-Candida drugs - the biochemical basis for their activity. CRC Crit Rev Microbiol 1987; 15: 57-72.

12 Del Poeta M, Barchiese F, Morbiducci V, et al. Comparison of broth dilution and semisolid agar dilution for in vitro susceptibility testing of Cryptococcus neoformans. J Chemother 1994; 6: 173-6.

13 Franzot SP, Hamdan JS. In vitro susceptibilities of clinical and environmental isolates of Cryptococcus neoformans to five antifungal drugs. Antimicrob Agents Chemother 1996; 40: $822-4$.

14 Pujol I, Guarro J, Gené J. Sala J. In-vitro antifungal susceptibilities of clinical and environmental Fusarium spp. strains. J Antimicrob Chemother 1997; 39: 163-7.

15 Wildfeuer A, Seidi HP, Paule I, Haberreiter A. In vitro evaluation of voriconazole against clinical isolates of yeasts, moulds and dermatophytes in comparison with itraconazole, ketoconazole, amphotericin B and griseofulvin. Mycoses 1998; 41: 309-19.

16 Dannaoui E, Persat F, Monier M-F, Borel E, Piens M-A, Picot S. In-vitro susceptibility of Aspergillus spp. isolates to amphotericin B and itraconazole. J Antimicrob Chemother 1999; 44: 553-5.

17 Omar S, Lemonnier B, Jones N, et al. Antimicrobial activity of extracts of eastern North American hardwood trees and 
relation to traditional medicine. J Ethnopharmacol 2000; 73: $161-70$.

18 DeMuri GP, Hostetter MK. Resistance to antifungal agents. Microb Resist Pediatr 1995; 42: 665-85.

19 VandenBossche H, Warnock DW, Dupont B. et al. Mechanisms and clinical impact of antifungal drug resistance. J Med Vet Mycol 1994; 32: 189-202.

20 Bard M, Lees ND, Barbuch RJ, Sanglard D. Characterization of a cytochrome P450 deficient mutant of Candida albicans. Biochem Biophys Res Commun 1987; 147: 794-800.

21 Broughton MC, Bard M, Lees ND. Polyene resistance in ergosterol producing strains of Candida albicans. Mycoses 1991; 34: 75-83.

22 Mahoney N, Molyneux RJ, Campell BC. Regulation of aflatoxin production by napthoquinones of walnut (Juglans regia). J Agricult Food Chem 2000; 48: 4418-21.

23 Oloke JK, Kolawole DO, Erhun WO. Antimicrobial effectiveness of six paradols. 1: a structure-activity relationship study. J Ethnopharmacol 1989; 25: 109-13.

24 Roth GN, Chandra A, Nair MG. Novel bioactivities of Curcuma longa constituents. J Nat Prod 1998; 61: 542-5.

25 Goto C, Kasuya S, Koga K, Ohtomo H, Kagei, N. Lethal efficacy of extract from Zingiber officinale (traditional Chinese medicine) or [6]-shogaol and [6]-gingerol in Anisakis larvae in vitro. Parasitol Res 1990; 76: 653-6.

26 Habsah M, Amran M, Mackeen MM, et al. Screening of Zingibereaceae extracts for antimicrobial and antioxidant activities. J Ethnopharmacol 2000; 72: 403-10.

27 Mowrey DB, Clayson DE. Motion sickness, ginger, and psychophysics. Lancet 1982; 20: 655-7.
28 Wood CD, Manno MJ, Wood BR, Mims, ME. Comparison of ginger with various antimotion sickness drugs. Clin Res Practices Drug Regulat Affairs 1988; 6: 129-36.

29 Bone ME, Wilkinson DJ, Young JR, McNeil J, Charlton S. Ginger root-a new antiemetic. The effect of ginger root on postoperative nausea and vomiting after major gynecological surgery. Anaesthesia 1990; 45: 669-71.

30 Fischer-Rasmussen W, Kjær SK, Dahl C, Asping U. Ginger treatment of hyperemesis gravidarum. Eur J Obstet Gynecol Reprod Biol 1990; 38: 19-24.

31 Arnason JT, Hebda R, Richard J, Johns T. Use of plants for food and medicine by Native peoples of eastern Canada. Can J Bot 1981; 59: 2189-325.

32 Kwon-Chung KJ, Bennett J. Medical Mycology. Philadelphia: Lea \& Febiger, 1992.

33 Abbas J, Bodey GP, Hanna HA, et al. Candida krusei fungemia. An escalating serious infection in immunocompromised patients. Arch Intern Med 2000; 160: $2659-64$.

34 Romano C, Asta F, Massai L. Tinea incognito due to Microsporum gypseum in three children. Pediatr Dermatol 2000; 17: 41-4.

35 Fidel PL, Jr., Vazquez JA, Sobel JD. Candida glabrata: review of epidemiology, pathogenesis and clinical disease with comparison to C. albicans. Clin Microbiol Rev 1999; 12: 80-96.

36 Stermitz FR, Lorenz P, Tawara JN, Zenewicz LA, Lewis K. Synergy in a medicinal plant: antimicrobial action of berberine potentiated by 5 'methoxyhynocarpin, a multidrug inhibitor. Proc Natl Acad Sci USA 2000; 97 : 1433-7. 